\section{REFERENCES}

Alvarez, A. S., and Summerskill, W. H. J. (1958). Lancet, 2, 920 .

Baragar, F. D., and Duthie, J. J. R. (1960). Brit. med. J., 1, 1106.

Batterman, R. C. (1958). New Engl. J. Med., 258, 213.

Blythe, R. H., Grass, G. M., and MacDonell, D. R. (1959). Amer. J. Pharm., 131, 206.

Brodie, B. B., Udenfriend, S., and Coburn, A. F. (1944). J. Pharmacol. exp. Ther., 80, 114.

Brown, R. K., and Mitchell, N. (1956). Gastroenterology, 31, 198.

Buckwaiter, J. A., van Scoy, R. E., and Knowler, L. E. (1960). Brit. med. J., 2, 1643.

Douthwaite, A. H. (1954). Lancet, 2, 917.

and Lintott, G. A. M. (1938). Ibid., 2, 1222.

Grahame, E. W. (1961). Brit. med. J., 1, 95

Grossman, M. I., Matsumoto, K. K., and Lichter, R. J. (1961). Gastroenterology, 40, 383.

Holt, P. R. (1960). J. Lab. clin. Med., 56, 717.
Hurst, A. (1943). Brit. med. J., 1, 768.

and Lintott, G. A. M. (1939). Guy's Hosp. Rep., 89, 173.

Kelly, J. J. (1956) Amer. J. ment. Sci., 232, 122.

Lange, H. F. (1957). Gastroenterology, 33, 770.

Lester, D., Loll, G., and Greenberg, L. A. (1946). J. Pharmacol. exp. Ther., 87, 329.

Matsumoto, K. K., and Grossman, M. I. (1959). Proc. Soc. exp. Biol. (N.Y.), 102, 517

Muir, A., and Cossar, I. A. (1955). Brit. med. J., 2, 7

Por (1959). Lancet, 1, 539.

Porter, I. H, Lewis, M., and Dixon, A. St. J. (1959). Ann. rheum. Dis., 18, 62.

Scott, J. T., Porter, I. H., Lewis, S. M., Dixon, A. St. J. (1961). Quart. J. Med., 30, 167.

Smith, M. J. H. (1951). J. Pharm. Pharmacol., 3, 409.

Smith, P K., Gleason, H. L., Stoll, C. G., and Ogorzalek, S. (1946). J. Pharmacol. exp. Ther., 87, 237.

Stubbé, L. Th. F. L. (1957). Thesis, Leyden.

(1958). Brit. med. J., 2, 1062

(1961). Ned. T. Geneesk., 105, 1673.

Summerskili, W H. J., and Alvarez, A. S. (1958). Lancet, 2, 925. Watson, R. M., and Pierson, R. N. (1960). Fed. Proc., 19, 191.

\title{
METFORMIN IN TREATMENT OF DIABETES MELLITUS
}

BY

\author{
B. GOTTLIEB, M.D., M.R.C.P. \\ Physician, St. Mary Abbots Hospital, \\ London
}

Since 1929 diguanides have been known to produce a hypoglycaemic effect in animals, but it was not until 1957 that phenylethyldiguanide (phenformin) and dimethyldiguanide (metformin) were tried in man. Related compounds, the guanidine derivatives, were shown to have a hypoglycaemic effect in animals (Watanabe, 1918). Frank et al. (1926) gave a full description of the effect of decamethylene-diguanidine (" synthalin") on diabetic patients, and the clinical scope appears to be similar to that of phenformin and metformin. Toxic effects, mainly on the gastrointestinal tract but occasionally involving the liver and kidneys (Frank, 1928), discouraged its further use.

A considerable amount of both clinical and physiological work has been done with phenformin, a full description of which appeared in the issue of Diabetes for May/June, 1960.

Metformin was synthesized by Werner and Bell (1922), and its hypoglycaemic effect on animals was described by Hesse and Taubmann (1929). Clinical trials were started in 1957, but so far only a few reports are available, mainly from France (Azerad and Lubetzki, 1959 ; Granville-Grossmann et al., 1959 ; Aubertin et al., 1960 ; Nahum, 1960 ; François and Ruiton Ugliengo, 1960 ; Lebon et al., 1961 ; Quillon, 1961).

In view of a report that side-effects with metformin are less likely to occur than with phenformin, a clinical trial was thought to be justified.

\section{Clinical Material}

The 39 patients ( 23 men and 16 women) in the trial included 20 who had previously been treated with insulin and 13 new cases. The others were previously unsatisfactorily controlled, 4 on diet alone and 2 with sulphonylurea derivatives. Three were cases of "pancreatic diabetes." One patient had chronic pancreatitis, one had carcinoma of pancreas, and a third had total pancreatectomy performed for carcinoma of pancreas. One patient suffered from steroid diabetes. The age distribution of the series is shown in Table I.

All the 39 patients were admitted to hospital for the initial trial period, usually of two to three weeks, during

\author{
W. H. R. AULD,* M.D., Ch.B. \\ Chemical Pathologist, Group Laboratory, \\ St. Mary Abbots Hospital, London
}

which they were on a 2,000-calorie diet, including 160-180 g. of carbohydrates. Thereafter they were seen regularly at the diabetic clinic. The response to metformin is shown in Table II.

Patients labelled as having a good response were those who felt well and in whom most of the urine tests each day were sugar-free. Those graded as having a partial response were those who required in addition to metformin either tolbutamide or insulin; they included one patient who previously required 84 units of insulin

TABLE I.-Age Distribution

\begin{tabular}{ll|c|c|c|c|c|c|c}
\hline Age &. & $21-29$ & $30-39$ & $40-49$ & $50-59$ & $60-69$ & $70-79$ & $80+$ \\
No. &.. & 2 & 5 & 4 & 6 & 10 & 7 & 5 \\
\hline
\end{tabular}

TABLE II.-Response to Metformin

\begin{tabular}{llll|c|c}
\hline & & & & Immediate & 6 Months \\
\hline Good response & $\ldots$ & $\ldots$ &. & 23 & 14 \\
Partial & $\ldots$ & $\ldots$ & $\cdots$ & 2 & 6 \\
Failed & $\ldots$ & $\ldots$ & $\cdots$ & 9 & 9 \\
Could not be assessed & $\ldots$ & $\cdots$ & 5 & 9 \\
\hline
\end{tabular}

plus $3 \mathrm{~g}$. of tolbutamide and who was satisfactorily controlled for over a year by $3 \mathrm{~g}$. of metformin and 3 g. of tolbutamide daily. Failure to respond was due to drug-resistance plus ketosis in eight cases, and included the three labelled "pancreatic diabetes." Side-effects were responsible for two of the failuresone patient having troublesome diarrhoea, the other nausea and vomiting. Two other patients had diarrhoea on doses of $3 \mathrm{~g}$. daily, but this symptom disappeared when the dose was reduced to $1.5 \mathrm{~g}$. daily. Those under the heading "Could not be assessed" included some whose dietary control was uncertain and it was sometimes difficult to tell whether diet restriction or drug therapy had brought about an improvement ; also included were some who had left the district and a follow-up of whom was not possible.

One patient in the unassessed group is worth special mention. He was a Yugoslav aged 31, with a history of polyuria and polydipsia for three weeks, whose diabetes

*Now at Ayrshire Area Laboratory, Ballochmyle Hospital, Mauchline, Ayrshire. 
was relatively mild with no tendency to ketosis. Fasting blood sugar was $180 \mathrm{mg}$. $/ 100 \mathrm{ml}$, rising to $354 \mathrm{mg}$./ 100 $\mathrm{ml}$. at two hours after $50 \mathrm{~g}$. of glucose. On metformin $1.5 \mathrm{~g}$. daily his diabetes became satisfactorily under control and remained so (while taking his tablets) for three months, when he ceased to attend the diabetic clinic. When next seen three months later-that is, six months after beginning treatment-he was feeling well, and the urine had been consistently sugar-free, although he had not taken metformin for three months. He remained on a restricted carbohydrate diet, and his weight was unchanged at 9 st. $10 \mathrm{lb}$. $(61.7 \mathrm{~kg}$.).

Dosage.-The daily requirement of metformin was found to be $1-3 \mathrm{~g}$. and was usually given in three divided doses. The usual practice was to start with $1.5 \mathrm{~g}$. daily in three divided doses and to increase if necessary to $3 \mathrm{~g}$. It was thought that nausea, vomiting, or diarrhoea was less likely to occur on this routine.

\section{Results}

Effect in Patients with Tendency to Ketosis.-Ten patients had displayed a tendency to ketosis prior to the trial. The assessment of the series after six months is shown in Table III. It appeared that severe ketosis was a contraindication to the use of metformin alone. Two patients with brittle diabetes who were treated with a combination of insulin and metformin did not benefit from the addition of metformin and were later put back on insulin alone.

Previous Insulin Treatment.-Twenty of the patients in this study had been on insulin prior to the trial. The assessment after six months is shown in Table IV. Our findings in this small series suggest that, provided the patient has no tendency to ketosis, a high dose of insulin need not contraindicate a trial with metformin. Our conversion procedure was to reduce the insulin dose by one-quarter every fourth day.

New Cases Treated with Metformin.-This group consisted of 13 cases. The blood sugars, fasting and at two hours after glucose, were within the range of $87-337 \mathrm{mg} . / 100 \mathrm{ml}$. and $257-436 \mathrm{mg} . / 100 \mathrm{ml}$. respectively. At six months five remained under satisfactory control; two showed a partial resistance and required tolbutamide in addition to metformin; five could not be assessed; and the only definite failure was a case of carcinoma of pancreas with diabetes mellitus.

Weight and Response to Metformin.-The relationship between weight and response to treatment in 37 cases

TABLE III.-Ketosis and Response to Metformin Therapy at Six

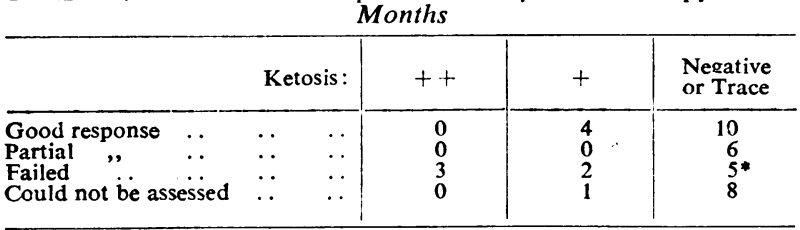

* Includes two failed cases due to side-effects.

TABle IV.-Previous Insulin Treatment and Response to Metformin at Six Months

\begin{tabular}{|c|c|c|c|c|}
\hline & Good & Partial & Failed & $\begin{array}{l}\text { Could } \\
\text { Not bs } \\
\text { Assessed }\end{array}$ \\
\hline $\begin{array}{l}\text { Under } 30 \text { units daily } \\
30-50 \text { units daily } \\
\text { More than } 50 \text { units daily }\end{array}$ & $\begin{array}{l}0 \\
4 \\
2\end{array}$ & $\begin{array}{l}0 \\
1 \\
2\end{array}$ & $\begin{array}{l}2^{*} \\
4 \\
3\end{array}$ & $\begin{array}{l}1 \\
0 \\
1\end{array}$ \\
\hline
\end{tabular}

is shown in Table V. It would appear that there is a better prospect of successful treatment in patients over 10 st. (63.5 kg.).

Age and Response.-For this assessment the patients were subdivided into three age-groups as shown in Table VI. Each group included one case of failure due to pancreatic diabetes. Only two out of seven cases in those under 40 showed an initial satisfactory response. By six months both had developed partial resistance and required tolbutamide in addition to metformin for satisfactory control. One of these was completely resistant to both drugs at 12 months, and required insulin for control.

Table V.-Weight and Response to Metformin at Six Months

\begin{tabular}{|c|c|c|c|}
\hline & & $\begin{array}{l}\text { Under } 10 \text { st. } \\
(63.5 \mathrm{~kg} .)\end{array}$ & $\begin{array}{l}\text { Over } \\
10 \text { st. }\end{array}$ \\
\hline $\begin{array}{l}\text { Good response } \quad \ldots \\
\text { Partial } " . \\
\text { Failed } \\
\text { Could not be assessed }\end{array}$ & $\begin{array}{ll}\because & . \\
\because & . \\
\because & \cdots \\
. .\end{array}$ & $\begin{array}{l}2 \\
2 \\
5\end{array}$ & $\begin{array}{c}10 \\
4 \\
5 \dagger \\
5\end{array}$ \\
\hline
\end{tabular}

* Includes one case of pancreatic diabetes. † Includes two cases of pancreatic diabetes.

TABle VI.-Age and Response to Therapy at Six Months

\begin{tabular}{|c|c|c|c|c|c|}
\hline & Age: & Under 40 & $40-59$ & $60+$ & Total \\
\hline $\begin{array}{l}\text { Good response } \\
\text { Partial " } \\
\text { Failed } \\
\text { Could not be assessed }\end{array}$ & $\begin{array}{l}\cdots \\
\cdots \\
\cdots\end{array}$ & $\begin{array}{l}0 \\
2 \\
3 \\
2\end{array}$ & $\begin{array}{l}6 \\
0 \\
2 \\
2\end{array}$ & $\begin{array}{l}8 \\
4 \\
5^{*} \\
5\end{array}$ & $\begin{array}{r}14 \\
6 \\
10 \\
9\end{array}$ \\
\hline Total & . & 7 & 10 & 22 & 39 \\
\hline
\end{tabular}

* Includes two cases of failure due to side-effects.

Time of Response to Metformin.-First signs of response appeared 2 to 12 days after the start of treatment-in the majority of cases about the fourth day. Maximum response was delayed in some cases until 12 to 14 days. It seems to us that treatment must be persevered with for a minimal period of two weeks on full doses before a case is to be regarded as definitely resistant to metformin.

Combined Therapy with Insulin or Tolbutamide.Metformin combined with insulin was given to five patients in whom metformin alone was ineffective. In one, a man aged 40, the insulin was reduced from 124 to 80 units daily, and although he felt well and his diabetes was under control, he was $1 \frac{1}{2} \mathrm{st}$. $(9.5 \mathrm{~kg}$.) lighter. Two patients with brittle diabetes seemed to derive no benefit from this combination, and were later changed back to insulin alone. In the two other patients no reduction in total insulin dose was possible. Metformin combined with tolbutamide was tried in five cases. One patient a woman aged 68 , with a history of diabetes for 14 years, who had no tendency to ketosis, was resistant to insulin, and had persistent glycosuria even with 184 units of insulin. After tolbutamide $3 \mathrm{~g}$. daily her dose of insulin was reduced to 84 units with a somewhat better measure of control of her diabetes. On the combination of $3 \mathrm{~g}$. of metformin plus $3 \mathrm{~g}$. of tolbutamide her diabetes came under satisfactory control and remained so for well over a year. After 18 months, however, she developed diarrhoea and could no longer tolerate more than $1.5 \mathrm{~g}$. of metformin daily, which did not adequately control her diabetes. Four other patients who were satisfactorily controlled initially with metformin became partially resistant between three and six months and were subsequently satisfactorily controlled on metformin and tolbutamide for periods up to one year. One of these patients, aged 21, after 
one year became resistant to both tolbutamide and metformin and required insulin for control.

\section{Comment}

In our small series the type of patient who appeared to respond best was over the age of 40 , had no tendency to severe ketosis, and was not suffering from " pancreatic diabetes"-the type of case, in fact, that may well respond to sulphonylureas. Metformin can therefore be considered in such cases if there is complete or partial resistance to the sulphonylurea derivatives. Two of our cases were resistant to tolbutamide but responded satisfactorily to metformin.

Although in this trial a response to metformin occurred initially in some adults of all ages, this did not persist in those under 40 . It is possible that the drug may sometimes be successful under the age of 40 if there is no tendency to ketosis, but it seems likely that resistance may develop subsequently. When partial resistance to metformin develops, as it did in four cases at the end of six months, a satisfactory response may occur when tolbutamide is added to the metformin. In one of these cases, that of a man aged 21 , resistance to both substances finally developed at the end of one year, and insulin became necessary.

Metformin seemed to have no place in the treatment of "pancreatic diabctes." Our three cases were completely resistant to this treatment and required insulin, small doses of 10-20 units being effective in two.

A case of steroid diabetes which responded satisfactorily to metformin deserves special comment. A woman of 47 suffering from rheumatoid arthritis for many years required $15 \mathrm{mg}$. of prednisolone daily to control her symptoms. Periodic urine tests revealed no glycosuria until six years after beginning treatment, when she had intermittent glycosuria, with blood sugar of $87 \mathrm{mg} . / 100 \mathrm{ml}$. fasting and $256 \mathrm{mg} . / 100 \mathrm{ml}$. two hours after food. Because of the activity of the rheumatoid arthritis the same dose of prednisolone was continued and, despite a lowered carbohydrate intake, her glycosuria persisted. She responded very satisfactorily to metformin, and eight months later remained sugar-free although still continuing with the same dose of prednisolone.

Side-effects in this series were troublesome enough to cause the drug to be stopped in two cases, one having nausea and occasional vomiting, and the other diarrhoea. Other patients had slight anorexia, but when given their metformin tablets with the meals this tendency disappeared. Diarrhoea appeared in two other cases when metformin was given in full doses of $3 \mathrm{~g}$. daily, but the symptom disappeared when the dose was reduced to $1.5 \mathrm{~g}$. None of our patients showed evidence of liver or kidney damage. One patient periodically passed in the urine small uric acid calculi $2-3 \mathrm{~mm}$. in diameter while on metformin therapy. These produced no symptoms. Their relation to the treatment is uncertain.

Mode of Action of Diguanides.-The mode of action of diguanide products has not been definitely determined. There is evidence to suggest that they act on the oxidative phase of carbohydrate metabolism, where they block the transfer of high-energy bonds to adenosinediphosphate, causing a diminution of oxygen uptake and leading to a condition of anoxia, which in turn increases the rate of anaerobic glycolysis and so lowers the blood sugar (Kruger et al., 1960).

\section{Summary}

A clinical trial of metformin in 39 adult cases of diabetes mellitus is described. Six months after starting treatment 14 showed a satisfactory degree of control on metformin alone. Six other cases showed some improvement when metformin was combined with either tolbutamide or insulin.

Three cases of pancreatic diabetes did not respond to metformin.

One case of steroid diabetes was satisfactorily controlled on metformin alone despite the continuation of prednisolone.

Side-effects severe enough to stop treatment occurred in only two cases.

\section{REFERENCES}

Aubertin, E., Roy, A., and Wone, Ch. (1960). Diabète (Le Raincy), 8, 5

Azerad, E., and Lubetzki, J. (1959). Presse méd., 67, 765.

François, R., and Ruiton Ugliengo, A. (1960). Diabète (Le Raincy), $8,98$.

Frank, E. (1928). Med. Klin., 24, 563.

Nothmann, M., and Wagner, A. (1926). Klin. Wschr., 5, 2100.

Granville-Grossmann, K. L., Crawfurd, S., Crowley, M. F., and Bloom, A. (1959). Brit. med. J., 2, 841.

Hesse, E., and Taubmann, G. (1929), Naunyn-Schmiedeberg's Arch. exp. Path. Pharmak., 142, 290.

Kruger, F. A., Skillman, T. G., Hamwi, G. J., Grubbs, R. C., and Danforth, N. (1960). Diabetes, 8, 170.

Lebon, J., Claude, R., Leutenegger, M., Galley, P., and Tricoire, J. (1961). Diabète (Le Raincy), 9, 159.

Nahum, A. (1960). Ibid., 6, 257.

Quillon, J. (1961). Ibid., 9, 172.

Watanabe, C. K. (1918). J. biol. Chem., 33, 253.

Werner, E. A., and Bell, J. (1922). J. chem. Soc., 121, 1790.

\section{SIGNIFICANCE OF HAEMOGLOBINS $S$ AND C IN GHANA}

\author{
BY
}

\section{G. R. THOMPSON,* M.B., M.R.C.P., D.T.M.\&H. \\ Captain, R.A.M.C.; late Medical Specialist, Military Hospital, Accra, Ghana}

In Ghana almost $30 \%$ of the population are carriers of either haemoglobin S or C (Edington, 1959). In Accra, among 200 out-patients, the incidence of the sickle-cell trait was $17 \%$ and of the haemoglobin-C trait 10.5\% (Edington and Lehmann, 1954). The high incidence and pathogenic properties of these haemoglobins cause them to be of considerable clinical importance in Ghana. Since the discovery of haemoglobin S (Pauling et al., 1949) and of haemoglobin C (Itano and Neel, 1950) much knowledge has accumulated regarding their behaviour (reviewed by Zuelzer et al., 1956), but the role of haemoglobin $C$ has remained unproved (Lehmann, 1959).

Haemoglobin $S$ has a fairly wide distribution, and carriers of the sickle-cell trait occur in frequencies of up to $40 \%$ in Africa, $30 \%$ in India, and $17 \%$ in Greece (Allison, 1954). Homozygous carriers of haemoglobin S die before puberty from the effects of sickle-cell disease (Lehmann and Raper, 1956), and survival of the gene responsible has been attributed to the protection haemoglobin $S$ confers on heterozygous carriers against Plasmodium falciparum malaria. Much research has been carried out on this hypothesis and the literature has been reviewed by Allison (1957). One of the most important contributions was by Raper (1955), who

*Now at Queen Alexandra Military Hospital, Millbank. 